\title{
Formation of monopolies in a bipartite market
}

\author{
Formación de monopolios en un mercado bipartita \\ Manuel Enrique Rodriguez Achach* y Enrique Baquedano Pérez \\ Universidad Marista de Mérida, Mexico
}

Received 9 February 2015; accepted 4 August 2016

Available online 16 August 2017

\begin{abstract}
We study the formation of monopolies in a simplified economic model where two brands compete in the market, using an agent based model. Each agent represents a company that uses one of the two available brands and interacts with other companies. The brands continually improve their product in order to compete for market share. In the innovation process companies can decide to change to the other brand if the move is beneficial. There is a cost for the company if it decides to switch to the other brand, and another cost if it stays with its current brand but only upgrades to a new enhanced version of the product. Our simulations show that the system always reaches a state when all companies end using a single brand, which is equivalent to a monopoly. We study the time span needed to reach the single brand final state for different parameters of the model.

(C) 2017 Universidad Nacional Autónoma de México, Facultad de Contaduría y Administración. This is an open access article under the CC BY-NC-ND license (http://creativecommons.org/licenses/by-nc-nd/4.0/).
\end{abstract}

Keywords: Monopoly; Competition; Market share; Simulation; Agent model

JEL classification: C63; D42

\section{Resumen}

Estudiamos la formación de monopolios en un modelo de economía simplificada donde dos marcas compiten por el mercado, usando un modelo basado en agentes. Cada agente representa una compañía que utiliza una de dos marcas disponibles e interactúa con las otras compañías. Las marcas continuamente mejoran su producto para poder competir en el mercado. En el proceso de innovación, las compañías pueden decidir cambiar a la otra marca si esto representa un beneficio. Existe un costo para la compañía asociado con el cambio de marca, y otro costo asociado si se queda con la misma marca pero decide adquirir una nueva versión del producto. Nuestras simulaciones muestran que el sistema siempre llega a un estado donde las

*E-mail address: mrodriguez@marista.edu.mx

Peer Review under the responsibility of Universidad Nacional Autónoma de México. 
compañías terminan utilizando una misma marca, lo que equivale a un mercado monopolístico. Estudiamos el tiempo requerido por el sistema para llegar al estado de monopolio para diferentes parámetros del sistema. (C) 2017 Universidad Nacional Autónoma de México, Facultad de Contaduría y Administración. Este es un artículo Open Access bajo la licencia CC BY-NC-ND (http://creativecommons.org/licenses/by-nc-nd/4.0/).

Palabras clave: Monopolio; Competencia; Cuota De Mercado; Simulación; Modelo De Agentes Códigos JEL: C63; D42

\section{Introduction}

Economic markets are very complex entities that display a rich variety of behaviors that result from the interaction of all the actors present in the economy; in fact, they are one of the classic examples in complexity theory. The use of models and computer simulations helps to shed some light in the underlying causes that create the market forces and can be used as a tool for decision making. Many economic problems can be studied with this technique, for example the shape and distribution of price changes (Ghashghaei, Breyman, Peinke, Talkner, \& Dodge, 1996), portfolio selection and optimization (Baviera, Pasquini, Serva, \& Vulpiani, 1998; Venegas Martínez \& Rodriguez Nava, 2009), the distribution of wealth (Burda et al., 2002; Hayes, 1990) and financial market models (Bouchaud \& Cont, 1998; Caldarelli, Marsili, \& Zhang, 1997; Mosqueda Almanza \& Guillén, 2012), among other subjects.

Competition can be found not only in economics but also in several disciplines. The first theoretical studies on competition were those devoted to population dynamics that investigated the competition of two species sharing the same ecosystem using the well-known Lotka-Volterra equations (Murray, 2002; Neal, 2004). In fact, the same methodology with little modifications has been extrapolated to study economic and financial problems (Kim, Lee, \& Ahn, 2006; Michalakelis, Sphicopoulos, \& Varoutas, 2011; Wijeratne, Yi, \& Wei, 2007). In addition to Lotka-Volterra equations and other types of differential equation systems (Dubois \& JodarRosell, 2010; Guha \& Chowdhury, 2013), competition in the economy has been recently studied using computer simulation models (Carpenter \& Lehmann, 1985; Tousi, Ghazanfari, \& Makui, 2015). However, there is little research on competition using the technique of agent-based models (Chiappori \& Salanie, 2008; Fu \& Szeto, 2009; Saracco, Di Clemente, Gabrielli, \& Pietronero, 2015). Simulation with agent-based models is a powerful method that allows the researcher to fine-tune the characteristics of the agents (companies, traders etc.) and of the interactions among them and is well suited to the study of the rivalry in an economy.

This paper deals with several basic concepts that will be defined before we go on. The monopoly, which arises in our simulations, is a situation where a person or enterprise is the only supplier of a particular good or service; therefore there is a lack of economic competition which may result in a high price well above the marginal cost of the good or service that results in a high monopoly profit (Friedman, 2002). Monopolistic competition is a type of imperfect competition where several producers sell products that are differentiated from one another (e.g. cereals) and hence are not perfect substitutes (Krugman \& Obstfeld, 2008). An oligopoly is a market dominated by a few sellers (oligopolists) that can lead to reduced competition and higher prices for consumers. A duopoly is a specific type of oligopoly where only two producers exist in a market.

In this paper we are interested in the study of brand competition in a bipartite market. We focus our study on industries where there is a large number of companies that have access to a 
very limited number of available products or technologies, and where the success of the company is directly related to the adoption of one of that product. As an example, consider the operating system for mobile phones, many different manufacturers of mobiles exist on the market, but they have limited choices for their operating system. Today, there are basically two options, Android and Windows Mobile. Nokia was one of the major manufacturers of mobiles in the past, but declined to switch to Android, and the result of that decision is well known. A similar situation arises in the air transportation industry for large airplanes, where Airbus and Boeing are the only manufacturers of large commercial airplanes.

It is important to recognize the difference between inter and intra brand competition. Inter brand competition refers to firms marketing differentiated products that compete on the basis of brands or labels; on the other hand, intra brand competition is competition between retailers or distributors of the same brand (Khemani \& Shapiro, 1993). We have constructed an inter brand competition model where companies can choose one of two available brands of a certain product or service. It is assumed that no other brands exist for the same product. The decision of which of the two brands will be selected by the company is based on a cost and payoff mechanism. The product or service has a certain cost, and the company will obtain a benefit or payoff from its use. The brands continually improve their products with new versions, and this innovation can persuade a company to switch to the other brand, or simply stay with the new version of the brand that is already using.

Innovation can be defined as the application of better solutions that meet new requirements, unarticulated needs, or existing market needs (Maryville, 1992). Technological innovation is directly related to economic performance, and that is the reason that drives companies to continually innovate their products. Empirical evidence shows that there is a positive link between innovation and economic growth (Ahlstrom, 2010).

Whether a company decides to make an expense in a new product is a decision that of course is influenced by many factors besides the associated costs. The monetary cost is almost always the main factor in the decision. The other factor that we take into account is the brand of the products that other related companies are using. This arises from the fact that the company will try to stay competitive and not lag behind what its competitors are doing. Therefore the decision is influenced by both the cost associated with the change and the brand of product that other companies are using. Other factors are excluded in order to keep the model as simple as possible.

\section{Description of the model}

Monte Carlo simulations have been successfully used in economics and finance since the seminal paper by Hertz (1964). In our model we consider a set of $N$ agents (companies) placed in a rectangular array. Companies can interact with their neighbors in the Moore neighborhood (the 8 companies around, see Fig. 1). Only these interactions are allowed to keep the model as simple as possible. The 8 companies that are neighbors of the central one can be the companies that have some commercial relations with that company, and not necessarily the neighbors in a spatial sense. Each company uses some kind of product or service of a certain brand (i.e. Android or Windows Mobile operating systems.). In our model, we consider that only two different brands for a product or service exist, say A and B (bipartite market). Companies are given initially one or the other brand at random.

Now suppose that a technological advance appears in one of the two brands, for example in A. One of the agents using brand A will now have a better product, and the neighbors of this agent may also want to switch to the new improved A brand, however, this change will have an 


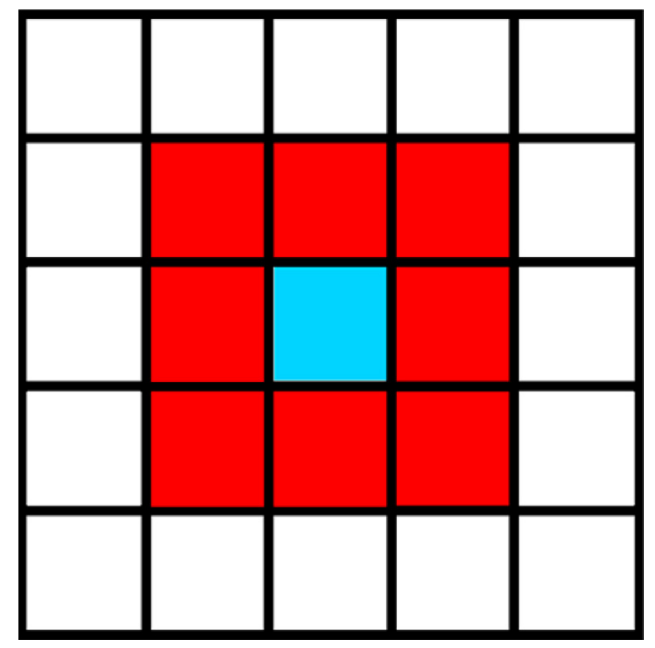

Figure 1. The Moore neighborhood used in the model. The central agent or company can interact with the eight agents that surround it.

associated cost. This cost will depend on whether the neighbor is also using brand A or is using the other brand. Typically the cost of upgrading the same brand is less than the cost of changing to a different brand. It may be the case that the neighbor does not want to change because the technological improvement is too small to compensate for the cost of upgrading or changing, and it may decide to wait for another version of the product to make the change. If the neighbor decides to upgrade or change, then its own neighbor may also want to do the same, and so on, until all agents change/upgrade or one decides not to do so and the process stops. At this point a new improvement in one of the brands enters the market and the process is repeated. The simulation therefore proceeds as follows.

A set of $N$ agents or companies is created. Each company is assigned at random a number that identifies the brand that uses ( 0 or 1$)$. The company is also assigned a real number $T$ that is a measure its technological level, or how new its product is. For example a company using Android 4.2 OS will have a higher value of $T$ than a company that still uses Android 3.9. It is assumed that companies are more competitive if they have better technology. A cost $C$ of upgrading is defined, this cost applies when a company wants to upgrade to a new version of the same brand. Another cost $S$ is defined that applies when the company wants to switch brands. Then:

(1) Randomly choose company and increase its technological level $T$. This will be the central company.

(2) For one of the eight neighbors of the chosen company, calculate the quantity $z=T_{i}-T_{c}-$ cost, where $T_{c}$ is the technological level of the central company, $T_{i}$ is the technological level of the neighbor and cost is $C$ if both companies use the same brand, or $S$ if the companies use different brands.

(3) If $z>0$ then the gain in technological level is greater than the cost and the neighbor company will upgrade or change its brand. Otherwise it stays with its current brand and technological level.

(4) Repeat steps (2) and (3) for all 8 neighbors.

(5) One time step has finished. Return to step (1). 
The formula $z=T_{i}-T_{c}-$ cost used to take the decision for the change or upgrade or brand, takes into account the difference in technological level among the company and its neighbors in the subtraction $\left(T_{i}-T_{c}\right)$, a positive result means that the neighbor company has better technology. To this result, we also subtract the cost of switching or upgrading, and if the final result is positive, that means that the company will benefit from the change. This of course is a simplification of the real process as we have commented before.

The process above is repeated $N$ times and this constitutes one MCS (Monte Carlo Step), which can be considered the unit of time. Simulations have been performed using an array of $10 \times 10$, for a total of 100 companies. Each simulation is repeated 2500 times to average the result.

The algorithm models the fact that each agent tries to imitate the technology of its neighbors, if the benefits justify the action. Running the simulation just presented we have found that the set of companies sooner or later will end up using a single brand. This monopoly state will take a long or short time to appear depending on the model parameters, but it seems to be unavoidable. Therefore, we study the times needed to reach the monopoly for different sets of the model parameters.

\section{Results and discussion}

In this work we have considered a particular type of industry where the market conditions are such that there is a large number of companies that can choose between a limited number ( 2 in our case) of brands of a certain product. It is assumed that the company survival is closely related to the brand of product that they use, because it can give a competitive advantage. The brands that form the oligopoly, in turn try to be more competitive to gain market share, by introducing technological advances in their product.

Such an industry can be exemplified by the mobile phone operating system industry. Initially, each manufacturer used a proprietary OS. With the passage of time, and the introduction of the smartphone, new multiplatform OS-s entered the market, and manufacturers had to choose among the different options. In today's market (with the exception of Apple's Iphone) all manufacturers of mobile phones have to choose between the Android or the Windows OS-s. In fact, the tendency is that Andoid will finally dominate the market and become a monopoly. Nokia is an example of a company that once dominated the market, but after a few commercial failures with new models, Android entered the market. Nokia refused to use Android, and the company continued to decline, until it was acquired by Microsoft in 2013. Other manufacturers of the time, and also the newcomers, followed the trend and used one of the two major OS-s, in other words, they are following a process of imitation of other companies in order to survive in the market.

The model always reaches a state of monopoly. We have covered a wide range of parameters and the result is the same. We have also used a Von Neumann neighborhood where only the closest 4 neighbors are considered (north, south, east and west), and the final fate does not vary. In a previous study in one dimension by Casillas, Espinosa, Huerta-Quintanilla, and RodriguezAchach (2006), even antimonopoly policies were introduced in the model and it was not possible to avoid the monopoly. The brand that ends up dominating the market is the one starts growing earlier, generally by a high technological innovation, initiating a positive-feedback effect. This phenomenon of a monopoly is also known as condensation in other fields, corresponding to one of two equivalent entities (brands in this case) growing and eliminating the other. It has been observed in previous works in economics (Arthur, 1990), Ising models in physics (Inoue \& Ohkubo, 2008; Laciana, Gual, Kalmus, Oteiza-Aguirre, \& Rovere, 2014), and opinion dynamics (Sznajd-Weron, 2000). 

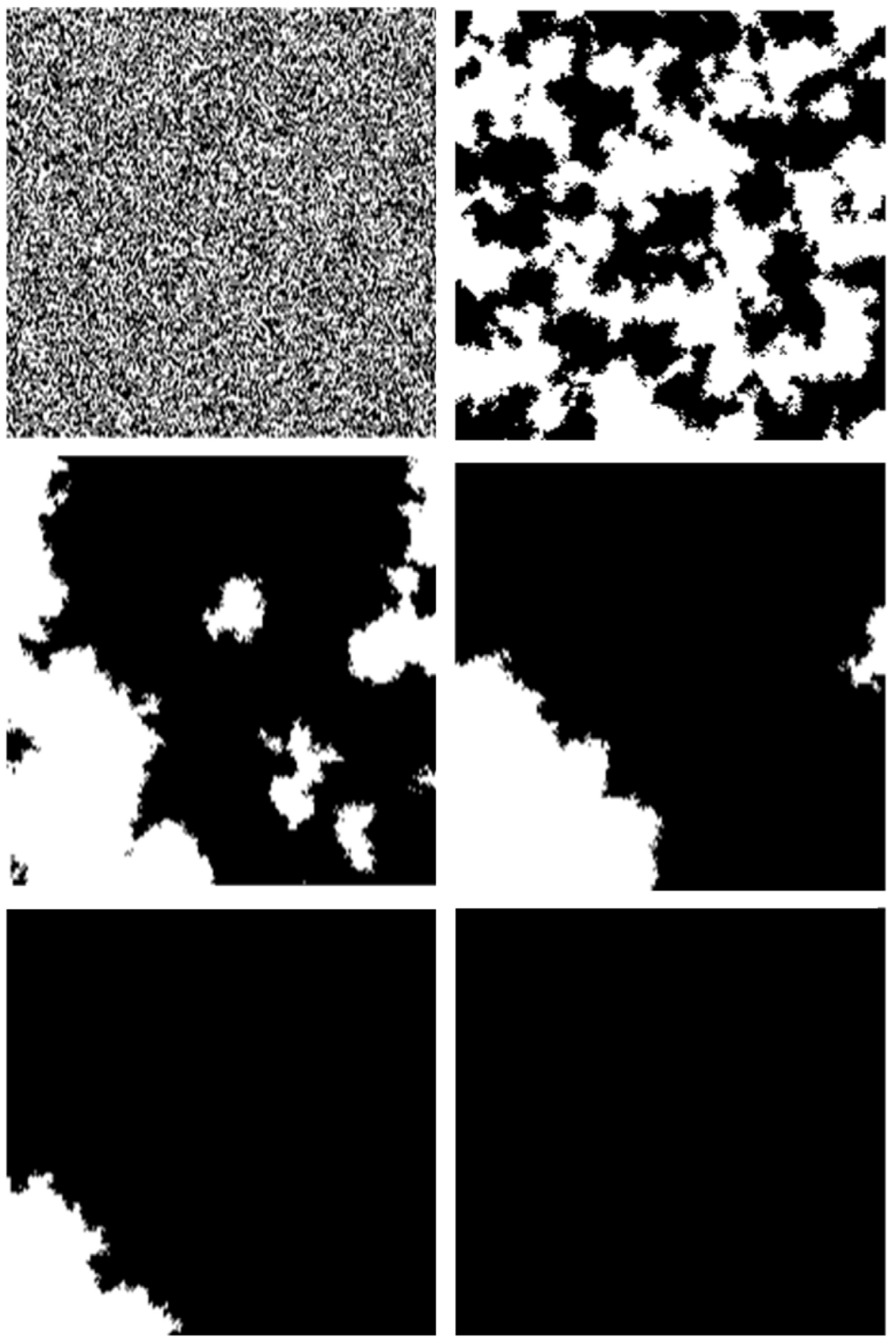

Figure 2. Evolution of brand market share. A system of 40,000 $(200 \times 200)$ companies using one of two brands (represented by black or white). From the initial random state in the upper left corner, the system evolves toward a state of monopoly where all the companies use a single brand (lower right corner). 


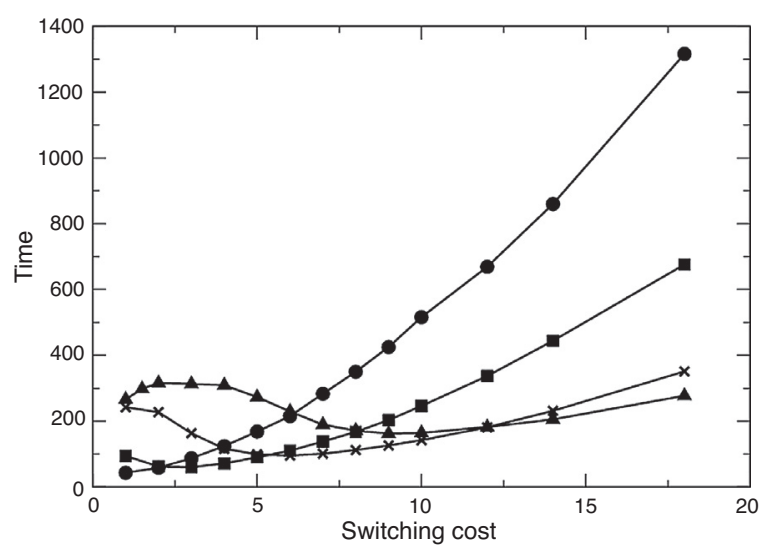

Figure 3. Time required to form a monopoly as function of the switching cost. Each curve is for a particular value of upgrading cost: $C=1$ for circles, 3 for squares, 7 for crosses and 12 for triangles.

The typical evolution of the model starts with a random placement of brands among the companies and, as the simulation of the competition process evolves in time, we see the formation of small clusters of same-brand companies. These clusters start to grow by coalition with other clusters. Eventually we have only two giant clusters, one of each brand, and finally one of them grows at the expense of the other and dominates the market to form the monopoly. This is illustrated in Figure 2.

The time needed to reach the monopoly state depends on the cost of upgrading $C$ and the cost of switching $S$. The size of the system (i.e. the number of companies) also increases the time needed to reach the monopoly, as expected. In Figure 3 we show the results for time as function of the switching cost $S$. Each curve corresponds to a different value of the upgrading $\operatorname{cost} C$. In general, times are longer for higher values of the switching cost. This behavior arises because more time steps need to pass until the earnings are high enough to offset a high switching cost $\mathrm{S}$. The curves of high upgrading cost show an anomalous behavior for small $S$, we see that times initially increase, then decrease and finally increase again. However, it is unrealistic to observe a higher value of upgrading that that of switching to a different brand.

The behavior is different when we plot the time as function of the upgrading $\operatorname{cost} C$ (see Fig. 4). Each curve corresponds to a different value of switching cost. Here we can see that the time for a monopoly state reaches a maximum value. In the curves for small $S$, the time increases until it reaches a maximum. The curves for higher value of switching cost show first a descent in time and then an increase before reaching the final value. This saturation value for time arises because, if the upgrading cost is too high compared to the switching cost, a company will prefer to switch its brand as soon as it can (when one of its neighbors begins using a different brand).

All the previous simulations were performed using a system size of $10 \times 10$, or 100 companies. We have also performed simulations on larger systems and the results are essentially the same but, as expected, the times needed to reach the monopoly are longer. This is illustrated in Figure 5, where we plot the curves for $C=3$ as function of the switching cost $S$ for a system of 100 companies and also for a system of 400 companies.

The time that the system needs to reach the monopoly state increases with the number of companies almost linearly, as can be seen in Figure 6, where we can see the resulting times for systems up to 5000 companies. 


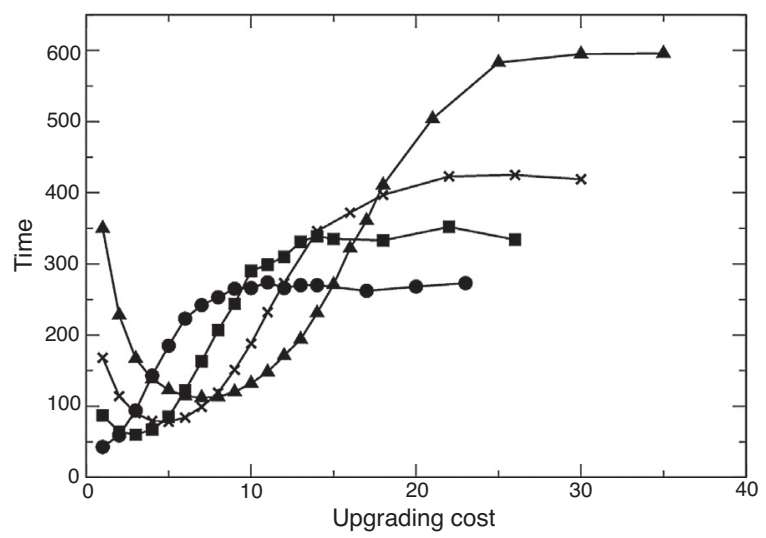

Figure 4. Time required to form a monopoly as function of the upgrading cost. Each curve is for a particular value of switching cost: $S=1$ for circles, 3 for squares, 5 for crosses and 8 for triangles.

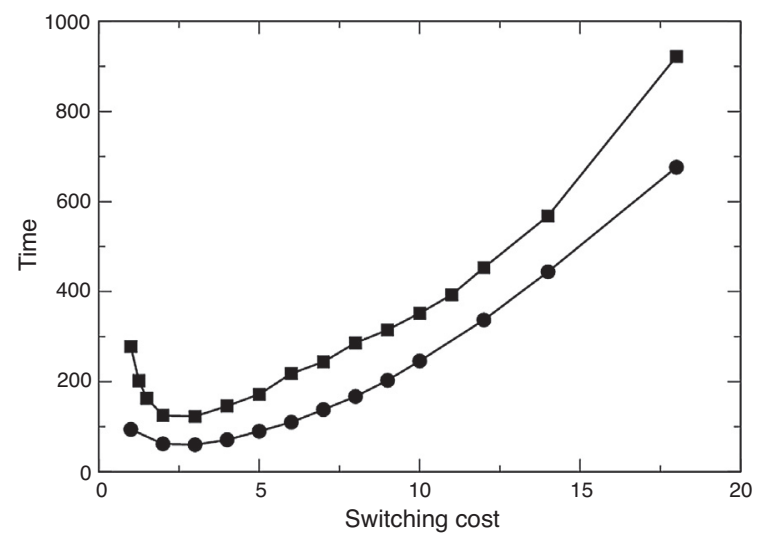

Figure 5. Comparison of times needed to form the monopoly for two system sizes: 100 companies (circles) and 400 companies (squares). In both curves the upgrading cost $C$ is 3 .

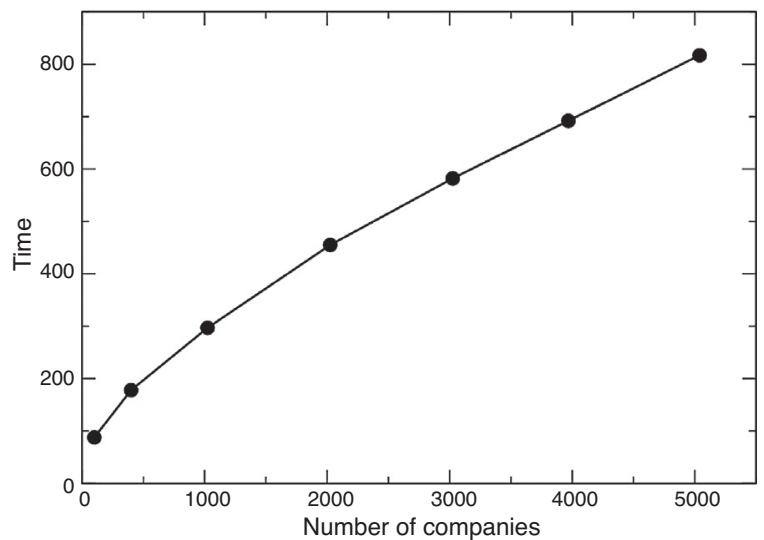

Figure 6. The time to reach the monopoly state increases with system size. The parameters used are $C=3$ and $S=5$. 


\section{Conclusions}

We have developed a computer model to study the competition of brands in a market, using Monte Carlo simulations. The model is robust and allows a wide range of parameters to be studied. One of the benefits of the use of an agent-based model is that it is relatively easy to refine the model with additional characteristics that one may want to study, in this way our model can be used and extended to cover more realistic situations by other researchers in the field. For example one can introduce more than two companies or a limited supply of the new products.

Our results show that a monopoly is formed sooner or later for any set of parameters of the model. In a previous work (Casillas et al., 2006), this model was studied in a one dimensional system with the same results. We have now showed that increasing the dimensionality to two does not prevent the monopoly state to be reached.

Although the model results suggest that the monopoly is the "natural" fate in a capitalist economy, we have to take into account that we are studying a particular type of industry, and our results cannot be generalized to other branches of the economic competition. It is also important to note that the different sectors of the economy behave differently with respect to the processes of innovation and imitation; therefore these results are not general of the whole economy. That sectors of the economy that rely heavily on high profile technology, such as the cell phone industry, will be more sensitive to the innovation process than, for example, the catering industry.

In present day economy, even with the myriad regulations that exist, almost every industry seems to be concentrated in a few hands. Some sectors of the economy that once were very competitive are now dominated by a few giant corporations. Whether or not the monopoly is unavoidable in the context of the type of industries considered in this work, is of course a question of paramount importance that deserves more research.

\section{Acknowledgements}

MRA wants to thank Javier Espinosa-Faller for useful discussions and Universidad Marista de Mérida for support on his sabbatical leave.

\section{References}

Ahlstrom, D. (2010). Innovation and growth: How business contribute to society. Academy of Management Perspectives, 24(3), 11-24, https://doi.org/10.5465/AMP.2010.52842948

Arthur, W. B. (1990). Positive feedbacks in economy. Scientific American, 262, 92-99, https://doi.org/10.1038/scientificamerican0290-92

Baviera, R., Pasquini, M., Serva, M., \& Vulpiani, A. (1998). Optimal strategies for prudent investors. International Journal of Theoretical and Applied Finance, 1, 473-486, https://doi.org/10.1142/S0219024998000254

Bouchaud, J. P., \& Cont, R. (1998). A Langevin approach to stock market fluctuations and crashes. The European Physical Journal B, 6, 543-550, https://doi.org/10.1007/s100510050582

Burda, Z., Johnston, D., Jurkiewicz, J., Kaminski, M., Nowak, M. A., Papp, G., \& Zahed, I. (2002). Wealth condensation in Pareto macro-economies. Physical Review E, 65, 026102, https://doi.org/10.1103/PhysRevE.65.026102

Caldarelli, G., Marsili, M., \& Zhang, Y. C. (1997). A prototype model of stock exchange. Europhysics Letters, 40, 479-483, https://doi.org/10.1209/epl/11997-00491-5

Carpenter, G. S., \& Lehmann, D. R. (1985). A model of marketing mix, brand switching, and competition. Journal of Marketing Research, 22(3), 318-329, https://doi.org/10.2307/3151428

Casillas, L., Espinosa, F. J., Huerta-Quintanilla, R., \& Rodriguez-Achach, M. (2006). Condensation in an economic model with brand competition. International Journal of Modern Physics C, 17(5), 749-756, https://doi.org/10.1142/S0129183106008832 
Chiappori, P., \& Salanie, B. (2008). Modeling competition and market equilibrium in insurance: Empirical issues. The American Economic Review, 98(2), 146-150, https://doi.org/10.1257/aer.98.2.146

Dubois, P., \& Jodar-Rosell, S. (2010). Price and brand competition between differentiated retailers: A structural econometric model. TSE working paper n. 10-159.

Friedman, M. (2002). Capitalism and freedom (40th anniversary ed.). Chicago: University of Chicago Press., https://doi.org/10.7208/chicago/9780226264189.001.0001

Fu, X., \& Szeto, K. Y. (2009). Competition of multi-agent systems: Analysis of a three-company econophysics model. Chinese Physics Letters, 26(9), 098901.

Ghashghaei, S., Breyman, W., Peinke, J., Talkner, P., \& Dodge, Y. (1996). Turbulent cascades in foreign exchange markets. Nature, 381, 767-770, https://doi.org/10.1038/381767a0

Guha, B., \& Chowdhury, P. R. (2013). Micro-finance competition: Motivated micro-lenders, double-dipping and default. Journal of Development Economics, 105, 86-102, https://doi.org/10.1016/j.jdeveco.2013.07.006

Hayes, B. (1990). Follow the money. American Scientist, 90, 400.

Hertz, D. B. (1964). Risk analysis in capital investment. Harvard Business Review Magazine (January/February issue).

Inoue, J., \& Ohkubo, J. (2008). Power-law behavior and condensation phenomena in disordered urn models. Journal of Physics A: Mathematical and Theoretical, 41(32), 324020, https://doi.org/10.1088/1751-8113/41/32/324020

Khemani, R. S., Shapiro, D. M. (1993). Glossary of industrial organisation economics and competition law, compiled by R. S. Khemani, \& D. M. Shapiro, commissioned by the Directorate for Financial, Fiscal and Enterprise Affairs, OECD.

Kim, J., Lee, J., \& Ahn, J. (2006). A dynamic competition analysis on the Korean mobile phone market using competitive diffusion model. Computers \& Industrial Engineering, 51, 174-182, https://doi.org/10.1016/j.cie.2006.07.009

Krugman, P. R., \& Obstfeld, M. (2008). International economics: Theory and policy (8th ed.). New Jersey: Prentice Hall.

Laciana, C. E., Gual, G., Kalmus, D., Oteiza-Aguirre, N., \& Rovere, S. L. (2014). Diffusion of two brands in competition: Cross-brand effect. Physica A: Statistical Mechanics and its Applications, 413, 104-115, https://doi.org/10.1016/j.physa.2014.06.019

Maryville, S. (1992). Entrepreneurship in the business curriculum. Journal of Education for Business, 68(1), 27-31.

Michalakelis, C., Sphicopoulos, T., \& Varoutas, D. (2011). Modeling competition in the telecommunications market based on concepts from population biology. Science, Man and Cybernetics, Part C: Applications and Reviews, 41(2), 200-210.

Mosqueda Almanza, R., \& Guillén, J. (2012). A model of medium term exchange rate forecast in an open economy. The case of the mexican peso. Contaduría y Administración, 59(2), 197-225.

Murray, J. D. (2002). Mathematical biology (3rd ed.). New York: Springer-Verlag.

Neal, D. (2004). Introduction to population biology. New York: Cambridge University Press.

Saracco, F., Di Clemente, R., Gabrielli, A., \& Pietronero, L. (2015). From innovation to diversification: A simple competitive model. PLOS ONE, 10(11), e0140420. http://dx.doi.org/10.1371/journal.pone.0140420

Sznajd-Weron, K. J. (2000). Opinion evolution in closed community. International Journal of Modern Physics C, 11(6), 1157, https://doi.org/10.1142/S0129183100000936

Tousi, M. A. S., Ghazanfari, M., \& Makui, A. (2015). A model of brand competition for durable goods supply chains in a dynamic framework. Journal of Industrial and Systems Engineering, 8(1), 61-85.

Venegas Martínez, F., \& Rodriguez Nava, A. (2009). Optimal portfolio and consumption decisions under exchange rate and interest rate risks. A jump-diffusion approach. Contaduría y Administración, 55(1), 9-24.

Wijeratne, A. W., Yi, F., \& Wei, J. (2007). Biffurcation analysis in the diffusive Lotka-Volterra system: An application to market economy. Chaos, Solitons and Fractals, 40(2), 902-911. 